\title{
Turbidity enhances feeding abilities of larval Pacific herring, Clupea harengus pallasi
}

George W. Boehlert ${ }^{1.2}$ \& John B. Morgan'

1 College of Oceanography and Marine Science Center, Oregon State University, New'port, OR 97365. U.S.A.

2 Present address: Southwest Fisheries Center Honolulu Laboratory, National Marine Fisheries Service, NOA A, P.O. Box 3830, Honolulu, HI 96812, U.S.A.

Keywords: larvae, feeding, turbidity, volcanic ash, estuaries

\begin{abstract}
Fishes inhabiting estuaries, rivers, and embayments are subject to turbid conditions. Larvae of many fishes utilize estuaries as nursery areas. For visual plankton feeders such as larval fishes, turbidity may reduce search and reaction distances, resulting in lowered feeding abilities. In this study feeding Pacific herring larvae, Clupea harengus pallasi, were exposed to suspensions of estuarine sediment and Mount Saint Helens volca nic ash at concentrations ranging from $0 \mathrm{mg} \cdot \mathrm{l}^{-1}$ to $8000 \mathrm{mg} \cdot \mathrm{l}^{-1}$. In all experiments, maximum feeding incidence and intensity occurred at levels of suspension of either $500 \mathrm{mg} \cdot \mathrm{l}^{-1}$ or $1000 \mathrm{mg} \cdot \mathrm{1}^{-1}$ with values significantly greater than controls $\left(0 \mathrm{mg} \cdot \mathrm{l}^{-1}\right)$. Feeding decreased at greater concentrations. The suspensions may enhance feeding by providing visual contrast of prey items on the small perceptive scale used by the larvae. Larval residence in turbid environments such as estuaries may serve to reduce predation from larger, visual planktivores, while searching ability in the small larval perceptive field is not decreased.
\end{abstract}

\section{Introduction}

Estuaries serve as important nursery areas for the larvae of a wide variety of fishes. Many species inhabit estuaries when turbidity is high, and indeed some species have been shown to prefer turbid conditions, at least as juveniles (Blaber \& Blaber, 1980). Larval fishes, particularly at first feeding, require high food densities and have relatively poor searching capabilities (Hunter, 1972, 1981). While zooplankton densities may occur at high levels within estuaries (Heinle \& Flemer, 1975), turbidity may result in suboptimal feeding conditions for larvae. The effects of turbidity on feeding, however, have not been determined for larval fishes.

Growth and survival of lake herring larvae (Coregonus) are not influenced by suspended sediments at low, naturally occurring concentrations (1-28 $\mathrm{mg} \cdot \mathrm{1}^{-1}$ ) (Swenson \& Matson, 1976). At higher concentrations, short term exposures to suspended sediment increase larval mortality (Auld \&

Hydrobiologia 123, 161-170 (1985).

(C) Dr W. Junk Publishers, Dordrecht. Printed in the Netherlands.
Schubel, 1978; Rosenthal, 1971; Sherk et al., 1975). Turbidities greater than $100 \mathrm{mg} \cdot \mathrm{l}^{-1}$ may occur in estuarine areas, particularly during tidal currents (Auld \& Schubel, 1978).

Large-scale mortalities often occur among captive larvae immediately following yolk absorption, implicating starvation as a major cause of death. Appropriately sized food particles must be present in high concentrations for significant survival and growth (Rosenthal \& Hempel, 1970; Hunter, 1972). Although Swenson \& Matson (1976) noted no effects of low turbidity on feeding of larval lake herring, greater turbidity decreases feeding rates in juvenile bluegill (Gardner, 1981), most likely through decreased prey availability (Vinyard \& O'Brien, 1976). Differences exist, however, between feeding behavior in larval and juvenile stages of fishes. Larvae are visual feeders with small search volumes; small larvae $(3-5 \mathrm{~mm})$ typically feed on particles about $0.050 \mathrm{~mm}$ wide (Hunter, 1981). In addition to lowered prey availability, larvae may 
consume suspended particles with food. This could result in blockage of the esophagus, preventing or hindering first feeding, as noted by Rosenthal (1971).

In this paper we report the effects of turbidity on feeding abilities of early larvae of the Pacific herring. Clupea harengus pallasi, a species which spawns in estuaries. Spawning occurs in Oregon and Washington estuaries in J anuary through early May (Steinfeld, 1972; Pearcy \& Meyers, 1974). Larvae remain in the estuarine nursery grounds through the juvenile stage. The estuary is commonly turbid during their residence, suggesting that feeding in turbid water is common for this species.

\section{Methods}

Two types of sediment suspensions were used in the experiments. Estuarine sediment was collected at low tide from mudflats in Yaquina Bay, Oregon. Volcanic ash from Mount Saint Helens was obtained from airfall ash at Moses Lake, Washington. This ash was dominated (weight percent fraction) by $0.020-0.045 \mathrm{~mm}$ particles (Fruchter et al., 1980). Both sediment and volcanic ash were standardized with respect to size by settling techniques. Particles larger than $0.024 \mathrm{~mm}$ were removed by settling over $10 \mathrm{~cm}$. Particles remaining in suspension were allowed to settle over $48 \mathrm{~h}$. After this time, the ash and sediment were treated differently. For both, the supernatant was siphoned off the settled material. For the volcanic ash, the remaining material was dried and the ash subsequently dispersed. The sediment was autoclaved and maintained in a liquified state to maintain particle separation; this solution typically contained about $80 \%$ water. Final particle sizes of volcanic ash and estuarine sediment were analyzed with a Coulter counter (Table 1). This particle distribution allowed maintenance of suspensions with the relatively low turbulence necessary for larva! fishes; for flow-through systems larger particles would have clogged the screens necessary to segregate the larvae. Secondly, the smaller particles may be more realistic with respect to what herring larvae may encounter in estuaries. Standardized suspensions $\left(\mathrm{mg} \cdot \mathrm{1}^{-1}\right)$ of sediment and ash were used to develop calibration curves of optical density; these curves were used to check the concentrations of suspensions during experiments.
Table 1. Particle size distribution of volcanic ash and estuarine sediment after settling and preparation for egg and larval experiments.

\begin{tabular}{|c|c|c|c|c|}
\hline \multirow{2}{*}{$\begin{array}{l}\text { Particle size } \\
\mu\end{array}$} & \multicolumn{2}{|c|}{ Sediment } & \multicolumn{2}{|l|}{ Ash } \\
\hline & $\begin{array}{l}c / c \text { by } \\
\text { number }\end{array}$ & $\begin{array}{l}\% \text { by } \\
\text { weight }\end{array}$ & $\begin{array}{l}\% \text { by } \\
\text { number }\end{array}$ & $\begin{array}{l}\% \text { by } \\
\text { weight }\end{array}$ \\
\hline $19.0-23.9$ & 0.1 & 3.9 & 0.1 & 3.8 \\
\hline $15.1-19.0$ & 0.3 & 8.0 & 0.6 & 8.7 \\
\hline $12.0-15.1$ & 1.0 & 12.1 & 2.9 & 18.8 \\
\hline $9.5-12.0$ & 2.4 & 14.3 & 6.0 & 21.4 \\
\hline $7.5-9.5$ & 5.0 & 15.1 & 10.5 & 18.4 \\
\hline $6.0-7.5$ & 9.9 & 15.1 & 14.6 & 12.9 \\
\hline $4.8-6.0$ & 19.2 & 14.6 & 18.9 & 8.3 \\
\hline $3.8-4.8$ & 29.5 & 11.0 & 21.8 & 4.9 \\
\hline $3.0-3.8$ & 32.7 & 6.0 & 24.6 & 2.8 \\
\hline
\end{tabular}

The spectral absorbance characteristics of ash and sediment suspensions were determined on a Beckman DU-6 spectrophotometer with samples in a cuvette with a $1-\mathrm{cm}$ light path. At equivalent concentrations, light is more highly attenuated in sediment suspensions than in volcanic ash suspensions (Fig. 1). Volcanic ash, moreover, shows a flat spectral absorbance curve, as one might expect from the glassy, crystalline nature of the ash (Fruchter et al.. 1980). The absorbance of the estuarine sediment is heavily skewed towards shorter wavelengths.

All experiments were conducted at the Oregon State University Marine Science Center. The seawater system for these facilities draws water from Yaquina Bay during high tides to maintain salinities in excess of $27 \mathrm{~g} \cdot \mathrm{I}^{-1}$. For experimental use, the water was passed through a sand and gravel filter to remove particulate matter and then irradiated with ultraviolet light to eliminate pathogens. It was mixed with the appropriate amount of dechlorinated fresh water to bring the final salinity to $15 \mathrm{~g} \cdot \mathrm{1}^{-1}$, and held in a large aerated reservoir in a constant temperature room to allow equilibration to the desired temperature. Light in the constant temperature room, where all experiments were conducted, was maintained at an intensity of $80 \mathrm{ft}-\mathrm{c}$ at the water surface of experimental vessels; photoperiod was adjusted to reflect seasonal changes in day length.

Pacific herring spawn in Yaquina Bay during winter and early spring months. All work was conducted with naturally spawned eggs collected along 


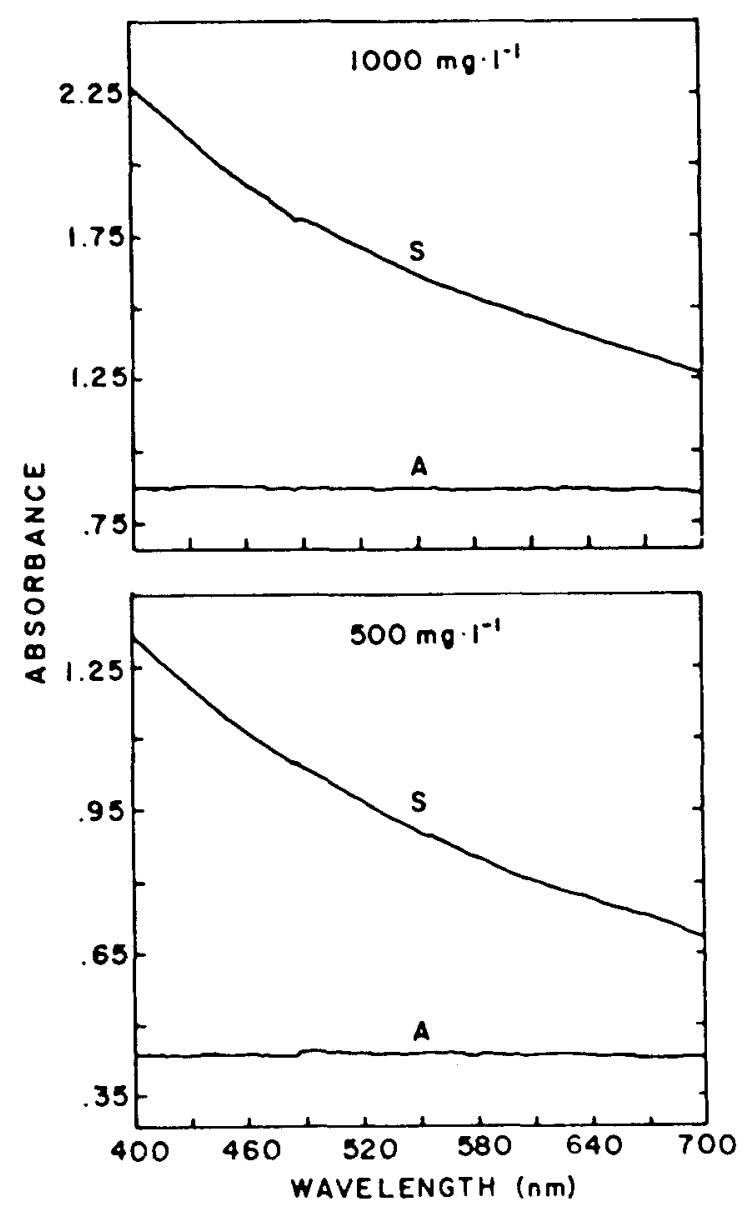

Fig. 1. Spectral absorbance characteristics and attenuation of visible light over a $1-\mathrm{cm}$ light path for two concentrations of estuarine sediment (S) and volcanic ash (A). At equivalent concentrations, the solutions differ in both spectral absorbance and optical density.

the north jetty of Yaquina Bay on 6 March and 14 April 1982. After bringing the eggs to the laboratory, they were placed in static 401 aquaria with aeration at $10^{\circ} \mathrm{C}$ in a constant temperature laboratory. Approximately $50 \%$ of the water was changed daily. As larvae hatched, they were moved to 2501 tanks prior to use in experiments. Larvae used for feeding experiments were monitored for yolk utilization and feeding ability. When specimens were capable of feeding, the rotifer Brachionus plicatilis, along with algal culture, was added to the tanks in densities which allowed a high rate of feeding.

Larval feeding experiments were conducted with the prey source consisting of the rotifer, B. plicatilis. Methods of mass culture of the rotifer followed Theilacker \& McMaster (1971). The marine planktonic alga, Isochri'sis sp. (Ewart \& Epifanio, 1981), was cultured as food for the rotifers. The average size of Brachionus was $0.220 \mathrm{~mm}$ long and $0.125 \mathrm{~mm}$ wide, a size acceptable to first feeding herring larvae. Rotifers were harvested for experiments by sieving through a $0.065 \mathrm{~mm}$ screen, washed in clean seawater, and placed in a larger vessel with algae overnight to acclimate to the $10^{\circ} \mathrm{C}$ experimental temperature.

Two types of experiments were conducted with feeding larvae. The first was based upon experiments which minimized turbulence and disturbance to the larvae during feeding trials. First-feeding clupeoid larvae are visual feeders with stereotyped behavioral sequences necessary for feeding (Hunter, 1972; Blaxter \& Staines, 1971). Therefore the excessive disturbance necessary for constant maintenance of given suspensions might inhibit feeding capabilities, resulting in very low feeding incidence even in controls. The two types of experiment were therefore based upon periodic suspension of ash or sediment in the first set and constant maintenance of the suspensions in the second set. This latter set of experiments resulted in higher turbulence but maintained mean suspension concentrations within $10 \%$ of the nominal value; thus lower feeding incidence was expected a priori.

The first set of experiments was conducted in 10-1 black circular tanks containing a total volume of 51 during the experiments. Larvae were chosen at times when all had initiated feeding; experiments were run on 24 and $25 \mathrm{March}$ with larvae aged 10 days posthatching (mean notochord length $8.7 \mathrm{~mm}$ ). On the night prior to the experiment, 100 to 200 larvae were introduced into 31 of water in the experimental vessel without food to allow evacuation of stomach contents. Preliminary experiments demonstrated that evacuation of identifiable food items occurred overnight. The following morning, an additional 21 of suspended ash or sediment was added to make final concentrations of $0,500,1000$, 2000,4000 , and $8000 \mathrm{mg} \cdot \mathrm{l}^{-1}$. The prey (B. plicatilis) was then added, followed by thorough stirring with a paddle, to begin the experiments. Food concentrations of six rotifers per milliliter initiated a well-defined feeding response in the larvae. The duration of the experiment was $2 \mathrm{~h}$ with resuspen- 
sion of ash or sediment concentrations at $15 \mathrm{~min}$ intervals. While this treatment kept turbulence low, it also resulted in some loss of suspension concentration. Separate trials were conducted to determine the change in suspension concentration at the surface, middle, and bottom of the experimental vessel at the end of the 15 min stirring interval. Monitoring the concentrations showed that the surface layer (top $0.5 \mathrm{~cm}$ ) densities decreased, averaging $32 \%$ lower than the nominal concentrations. In the middle depth, there was an average $16 \%$ decrease in concentration, and at the bottom of the containers, a $50 \%$ increase in concentration. A similar trend of changes in the densities of foud organisms was apparent, with increasing abundance of food particles in the denser ash or sediment at the bottom of the experimental vessels at the end of $15 \mathrm{~min}$. Experiments were terminated after $2 \mathrm{~h}$ by quickly sieving the suspensions and larvae through a $0.335 \mathrm{~mm}$ nylon screen and immediately preserving the larvae in 10\% Formalin to minimize regurgitation of food. These experiments were run in duplicate.

In the feeding experiments with continual suspension, an apparatus was designed to eliminate the need for manual suspensions of sediments and to maintain more uniform exposure of the suspensions. The device (Fig. 2) allowed testing of three replicate groups of larvae. Three 1-1 experimental chambers were cut from $10 \mathrm{~cm}$ (i.d.) black ABS plastic pipe covered at one end with $0.335 \mathrm{~mm}$ nylon mesh screen and connected in a rosette pattern to a center polyvinyl chloride pipe which supported both the chambers and an airlift device. The rosette was partially submerged in a round 101 black plastic tank containing the suspension of ash or sediment which was kept in suspension outside the chambers by a variable-speed stirrer. The nylon screen was small enough to contain the larvae and still allow suspensions and rotifers to be recycled back into the 101 container. A concave deflector helped to create a mixing area within the larger container. Two airstones placed beneath each center pipe airlifted the suspensions through three glass tubes ( $9 \mathrm{~mm}$ i.d.) which penetrated a rubber stopper within the center pipe. These glass tubes were bent at right angles at the top and directed into the three dosing chambers. The airlift system above the test containers was continued with $1.3 \mathrm{~cm}$ (o.d.) plastic tubing with three $3.6 \mathrm{~mm}$ holes bored along
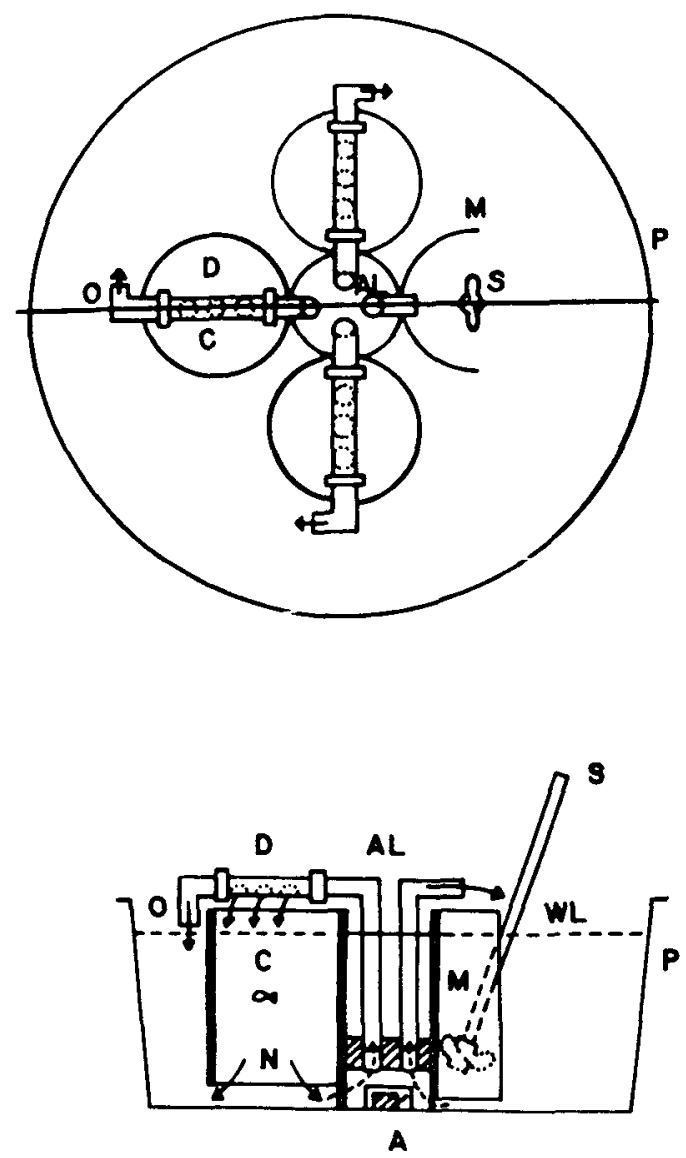

Fig. 2. The experimental apparatus used to maintain continuous suspensions of sediment or volcanic ash. Total volume of each container holding larvae was $1 \mathrm{l}$; the volume of the larger tank was 10 . Flow rate into the smaller containers was maintained at approximately $240 \mathrm{ml} / \mathrm{min}$. A, airstone. AL, airlift system. $C$, dosing chamber. $D$, flow regulator. $M$, mixing area. $N$, $0.335 \mathrm{~mm}$ nylon screen. $O$, overflow. $P, 10 \mathrm{l}$ tank. $S$, stirrer connected to variable speed motor. WL, water level. Arrows indicate the direction of flow of suspension through the apparatus.

one side to allow control of the volume of suspensions entering the test containers. Flow rates were maintained at approximately $240 \mathrm{ml} \mathrm{min}^{-1}$. In these experiments, larvae aged 22 days posthatching (mean notochord length $10.0 \mathrm{~mm}$ ) were used. Three replicates of about 20 larvae were tested per treatment, in which the suspensions were continually maintained. Again, larvae were preserved at the termination of experiments for later enumeration of feeding incidence and number of food particles. 
Preserved larvae were examined individually under a dissecing microscope for presence of food. This could be done without dissection as the gut is straight in herring larvae and the transparent gut wall makes observation possible (Checkley, 1982).

\section{Results}

The herring larvae used in all experiments readily fed upon B. plicatilis. A total of 1502 larvae were examined from the volcanic ash suspension feeding experiments and 1272 from the estuarine sediment feeding experiments, with an overall average of $69 \%$ and $74 \%$, respectively, of the larvae feeding during the 2-h duration of the experiment. In both sets of experiments, the percentage of larvae feeding increased dramatically from the control experiments to 500 and $1000 \mathrm{mg} \cdot \mathrm{l}^{-1}$ before showing a gradual decline with successive increases in sediment or ash concentrations to near that of the controls at $8000 \mathrm{mg} \cdot \mathrm{l}^{-1}$ (Fig. 3 ). In the ash suspensions, control larvae each consumed approximately 10 Brachionus whereas larvae at $500 \mathrm{mg} \cdot \mathrm{l}^{-1} \mathrm{con}$ sumed showed the maximum number, nearly 17. Values declined until those at $8000 \mathrm{mg} \cdot \mathrm{l}^{-1}$ were near those of the controls (Fig. 4A). A similar pat-

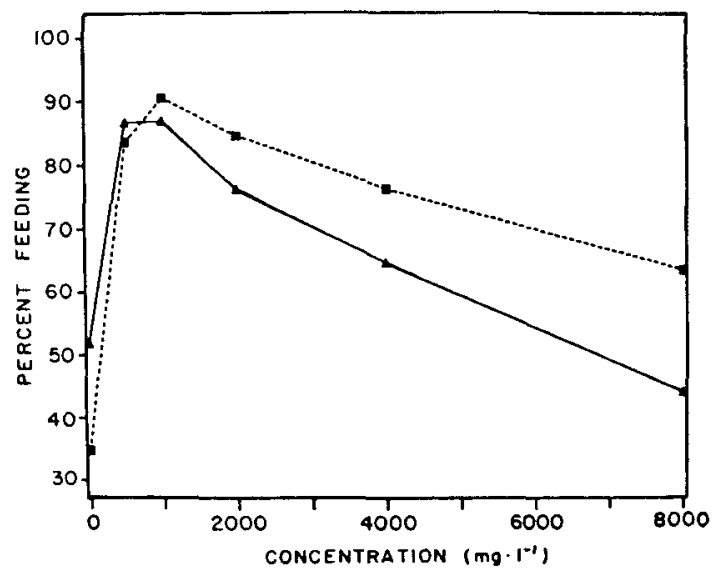

Fig. 3. Effects of periodically suspended estuarine sedment and volcanic ash upon the feeding success (percent feeding) of larval Pacific herring. Larvae were allowed to evacuate guts overnight; experiments were of $2-h$ duration with 6 Brachionus per milliliter in the suspensions. Solutions were uniformly resuspended by stirring every $15 \mathrm{~min}$ during the feeding period. Values are means of two replicates. Dashed line, estuarine sediment. Solid line, volcanic ash.

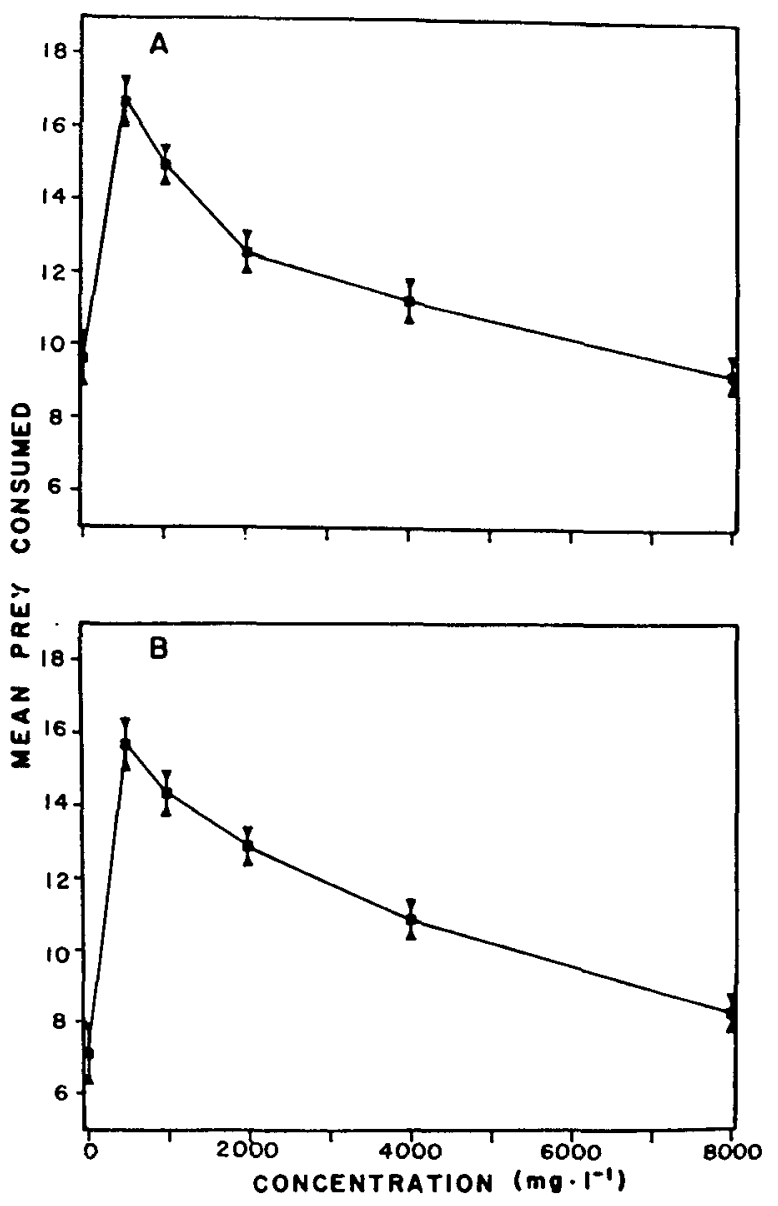

Fig. 4. Effect of periodic resuspensions upon the feeding success (prey consumed per feeding larva) in larval Pacific herring. Error bars indicate \pm 1 standard error. Numbers of feeding larvae range from 54 to 259. A, Volcanic ash. B, Estuarine sediment.

tern is seen for sediment suspensions (Fig. 4B). There was greater feeding incidence by larvae in sediment suspensions than in volcanic ash suspensions at concentrations in excess of $500 \mathrm{mg} \cdot \mathrm{l}^{-1}$. The effect of sediment on the number of prey ingested per larva was not significantly different (Wilcoxon matched-pairs signed-rank test, $P>$ 0.05 ) from that of ash.

Results from these semistatic feeding trials suggest that both sediment and volcanic ash stimulate feeding incidence and activity as compared to control fish. In these trials, the settlement of the suspended particles between stirring lowered the effec- 
tive suspension concentration in the tanks by the values described in the previous section. Swenson \& Matson (1976) noted that larval lake herring swim up the water column in response to suspended sediment. This may have occurred in these experiments as well, resulting in increased visibility of prey organisms in the near surface water of the test container with its lower concentration of suspension.

In the second set of experiments, suspensions remained within $10 \%$ of the nominal value during the course of the experiment. Feeding incidence was lower, averaging $31 \%$ for ash and $23 \%$ for sediment over all concentrations. As a function of concentration, the curves of feeding incidence for ash and sediment were not significantly different but showed a different trend from the semistatic experiments (Fig. 5). The percentage of larvae feeding was again initially greater than in the controls, but then decreased with increasing suspension concentration, reaching nearly zero at $4000 \mathrm{mg} \cdot \mathrm{l}^{-1}$ for sediment. In these experiments the variability in the numbers of Brachionus consumed per larva within experiments as well as within replicates was high (Fig. 6A, B), suggesting significant variability among individuals.

With increasing turbidity, number of Brachionus consumed also increased to a maximum at $1000 \mathrm{mg} \cdot \mathrm{H}^{-1}$ in the ash experiments (Fig. 6A) and

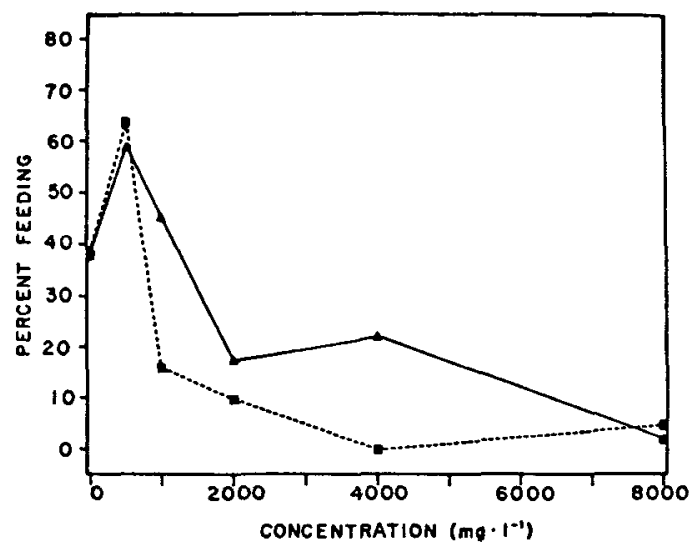

Fig. 5. Effects of continuous suspensions of estuaritue sediment and volcanic ash upon the feeding success of larval Pacific herring. Larvae were allowed to evacuate guts overnight; experiments were of 2 h duration with 6 Brachionus per milliliter in the suspensions. Values are the means of three replicates. Dashed line, estuarine sediment. Solid line, volcanic ash.

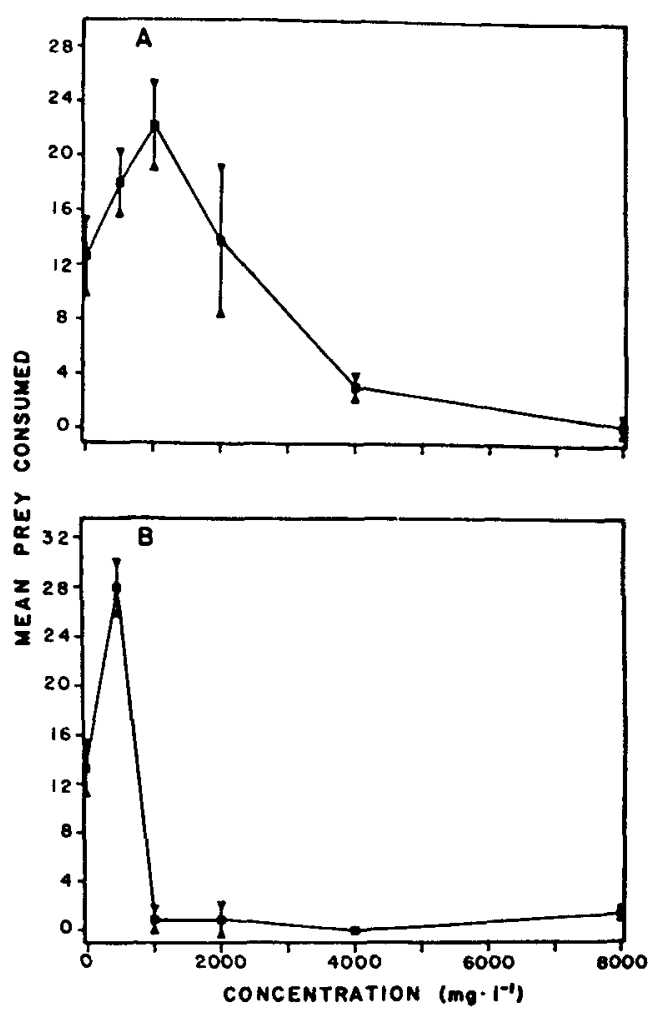

Fig. 6 . Effects of continuous suspensions on the feeding success (prey consumed per feeding larva) in larval Pacific herring. Error bars indicate \pm 1 standard error. Numbers of feeding larvae ranged from 0 to 42 . A. Volcanic ash. B, Estuarine sediment.

at $500 \mathrm{mg} \cdot \mathrm{l}^{-1}$ in the sediment experiments (Fig. 6B). In the sediment experiments, feeding at $1000 \mathrm{mg} \cdot 1^{-1}$ and higher was nearly zero. Equivalent values in volcanic ash were not reached until a concentration of $8000 \mathrm{mg} \cdot \mathrm{H}^{-1}$; values in volcanic ash suspensions greater than $500 \mathrm{mg} \cdot \mathrm{l}^{-1}$ were significantly greater than in sediment (Wilcoxon matched-pairs signed-rank test, $P<0.05$ ). The differences between the semistatic and dynamic feeding trials may be due either to the decreasing concentrations of sediment or ash in the upper levels of the semistatic tank in the intervals between stirring or to the greater turbulence in the dynamic experiments. In the dynamic trials, despite a turnover of $25 \%$ of the water in the experimental vessel per minute, larvae were clearly able to feed in lower concentrations of both ash and sediment (Figs. 5, 6A, B). While feeding incidence was gen- 
Table 2. Presence of ash or sediment in guts of larval herring from the feeding trials conducted 11 and $13 \mathrm{May}, 1982$. From each concentration. 20 larvae were examined.

\begin{tabular}{lcc}
\hline $\begin{array}{l}\text { Suspension concentration } \\
\text { (mg l) }\end{array}$ & \multicolumn{2}{c}{$\%$ incidence in larval guts } \\
\cline { 2 - 3 } & $\begin{array}{l}\text { Volcanic } \\
\text { ash }\end{array}$ & $\begin{array}{l}\text { Estuarine } \\
\text { sediment }\end{array}$ \\
\hline 0 & 0 & 0 \\
500 & $95 \%$ & $100 \%$ \\
1000 & $70 \%$ & $80 \%$ \\
2000 & $50 \%$ & $40 \%$ \\
4000 & $30 \%$ & $50 \%$ \\
8000 & $25 \%$ & $50 \%$ \\
\hline
\end{tabular}

erally lower than in semistatic experiments, the mean number of prey consumed per feeding larva was greater in the dynamic experiments for the controls and concentrations of 500,1000 , and $2000 \mathrm{mg} \cdot \mathrm{l}^{-1}$ in the ash suspensions (Figs. 4A, 6A) but only in the controls and $500 \mathrm{mg} \cdot \mathrm{H}^{-1}$ in the sediment suspensions (Figs. 4B, 6B). This difference, however, probably reflects the greater age of larvae in the dynamic experiments. We thus interpret the continued feeding by the larvae in the semistatic experiments at suspension concentrations greater than $2000 \mathrm{mg} \cdot \mathrm{I}^{-1}$ in ash and greater than $1000 \mathrm{mg} \cdot \mathrm{t}^{-1}$ in sediment to be a result of the decreasing concentration in the surface of the tank and possibly the behavioral movement of the larvae to this level as well.

In the feeding trials, sediment and as $h$ were taken into the gut in limited amounts. From the dynamic feeding experiments, groups of 20 larvae from each concentration were examined for presence or absence of ash or sediment in the intestine and also qualitatively for amount. Generally, with increased concentration of the suspension (beyond the control), the incidence of particles in the gut decreased (Table 2). Only in the highest concentration $\left(8000 \mathrm{mg} \cdot \mathrm{1}^{-1}\right)$ of both ash and sediment, were some individuals present with large amounts in the gut. Generally, only traces of ash or sediment were apparent. The observation of the greatest incidence at the lowest suspension concentration would support the contention that ingestion of ash or sediment was associated with feeding, since feeding incidence was also highest at these concentrations (Figs. 3, 5).

\section{Discussion}

Oviparous fishes which produce large numbers of small eggs suffer high mortality rates in early life history stages, mostly from starvation and predation (Hunter, 1976). Environmental pollution may further increase mortalities through either direct effects (Longwell \& Hughes, 1981; Hunter et al., 1979,1981 ) or indirect effects (Rosenthal \& Alderdice, 1976).

The effects of sediment on reproduction and early life stages of warmwater fishes have recently been reviewed by Muncy et al. (1979). A variety of effects, dependent upon species and type of sediment, is apparent. For eggs, the most consistent effect appears to be the reduction in respiratory gas exchange. Early larvae depend upon epidermis for respiratory gas exchange (Hunter, 1972; Weihs, 1980) thus a coating of particulates may hinder gas exchange. The epidermis in early larvae, furthermore, is only a few cells thick (O'Connell, 1981; Jones et al., 1966), making larvae subject to abrasion damage and other potentially sublethal effects (Boehlert, 1984).

$A$ priori, one would expect suspended particulates to affect larval fish feeding. First-feeding larvae are very small, have relatively small perceptive fields, and possess only weak swimming abilities; early larvae are thus able to search only limited volumes for food. Blaxter \& Staines (1971) showed that larval Atlantic herring, Clupea harengus harengus, the same age as those in the present study ( 10 and 22 days posthatching) searched only 0.2 to 0.51 per h. Compounding low search volume is a low feeding success rate, estimated to range from 10 to $30 \%$ (Blaxter \& Staines, 1971). Thus, based upon feeding success rate and volume searched it is obvious that first-feeding larvae require relatively high densities of food particles to survive. Laboratory studies of food density and its effect on feeding and survival confirm that very high densities are required. Experimental food densities for $50 \%$ survival range from $199 \mathrm{1}^{-1}$ for sea bream (Houde, 1978) to $40001^{-1}$ (northern anchovy, O'Connell \& Raymond, 1970).

For larvae to locate these high densities of food, visual orientation is critical; increased turbidity or other factors affecting visual field and perception may reduce food consumption and increase the probability of starvation. Gardner (1981) 
noted reduced feeding rates in juvenile bluegill exposed to bentonite clay concentrations of 400 to $1200 \mathrm{mg} \cdot 1^{-1}$; he observed no change, however, in size selectivity of available prey. Similarly, Moore \& Moore (1976) suggested that increased turbidity reduced the ability of flounder to see epibenthic prey, resulting in longer times for prey capture. Our results are thus unexpected. In both semistatic and continual suspensions of both estuarine sediment and volcanic ash, low suspension levels actually increased feeding rates (Figs. 4A, B; 6A, B) and the percentage of larvae feeding (Figs. 3, 5). Similar results were observed in filter feeding copepod, Eurytemora affinis; feeding rates were enhanced at $100 \mathrm{mg} \cdot \mathrm{l}^{-1}$ of Fuller's earth, but maximum ingestion rate decreased at particulate levels in excess of $250 \mathrm{mg} \cdot \mathrm{H}^{-1}$ (Sherk et al., 1975).

We suggest two possible mechanisms for enhanced feeding in sediment and ash suspensions. First, particulates may enhance visual contrast allowing larvae to better visualize their prey. In the controls, feeding incidence and the numbers of particles consumed per feeding larva were low; in these black-walled containers, however, feeding was nonetheless higher than in preliminary control experiments with glass-walled containers. Confer \& Blades (1975) and Confer et al. (1978) suggested that planktivorous fishes have greater reaction distances for more heavily pigmented prey. Similarly, the relatively transparent Brachionus may have been contrasted against the background of the suspensions. Based upon the spectral absorbance of the two solutions (Fig. 1), the sediment may have provided the greater contrast. A second explanation is based upon light scattering. In turbid water, particle scattering will disperse light in all directions. Thus Brachionus will be illuminated from all directions, possibly decreasing its transparency.

No great differences were apparent between ash and sediment for the larval feeding experiments. The lower concentrations of both ash and sediment resulted in enhanced feeding. In the dynamic experiments (Fig. 5), the feeding incidence was greatest at $500 \mathrm{mg} \cdot \mathrm{I}^{-1}$ for sediment and rapidly decreased thereafter, whereas the peak for volcanic ash was at $1000 \mathrm{mg} \cdot 1^{-1}$ and decreased less markedly. Light transmission through equivalent suspensions of ash and sediment differ, with significantly greater light transmission through the volcanic ash (Fig. 1). For visual feeders such as fish larvae, this difference in available light may cause the difference in feeding abilities. The spectral absorbance differences (Fig. 1) may also have played a role. Larval herring have only single cones in the retina (Blaxter \& Jones, 1967). Blaxter (1968) used behavioral measures to suggest three maxima $(450,520$, and $600 \mathrm{~nm}$ ) of photopic visual sensitivity in larval Atlantic herring. Action spectra for feeding on Balanus and Artemia nauplii, however, were dominated by wavelengths near 500-600 nm. At these longer wavelengths absorbance differences of equivalent concentrations of volcanic ash and sediment are less (Fig. 1).

A compariscn of the present data with that of Gardner (1981) and Moore \& Moore (1976) suggests that prey density and perceptive field may both play a role. Herring larvae 10 to 20 days old have a perceptive distance of only $3.5 \mathrm{~mm}$ (Blaxter \& Staines, 1971). In both of the past studies, larger fish, with correspondingly larger perceptive fields, were used; Vinyard \& O'Brien (1976) and Confer et al. (1978) suggested that turbidity reduces the reaction distance for feeding. With our study, it is therefore probable that the greater feeding incidence in suspensions of $500-1000 \mathrm{mg} \cdot \mathrm{l}^{-1}$ would be diminished with decreasing prey density and encounter rate. In nature, however, Doan (1941) suggested that turbidity might increase the abundance of microcrustaceans at the surface, resulting in enhanced larval feeding.

Another effect of turbidity-induced light reduction may be a change in the vertical distribution of larvae. This may have a great effect on larvae in estuaries, where vertical distribution may have important effects upon horizontal distribution. Swenson \& Matson (1976) observed a change in larval vertical distribution within test suspensions of sediment. We noted similar effects in the semistatic feeding experiments despite increased densities of Brachionus in the bottom of the tanks. Larval fishes generally use light intensity for depth regulation (Blaxter, 1974). Thus light attenuation from higher than normal turbidity may result in larvae occupying shallower depths. In estuarine fish larvae such as herring, depth regulation may be necessary to maintain populations within an estuary (Weinstein et al., 1980). This has been observed in larvae of Atlantic herring (Graham, 1972) and is probably true of Pacific herring as well. A distribution higher in the water column could therefore result in advec- 
tion out of the estuary and probable increases in mortality.

A possible benefit of larval fish residence in moderately turbid estuaries with lower light levels may be reduced predation pressure. Howick \& O'Brien (1983) noted that prey behavior and motion is an important component of predator success. It is thus conceivable that larval herring reduce feeding activity under high light levels (low turbidity), and that the observed feeding pattern is behaviorally determined. This is not supported, however, by behavioral observations; although Blaxter (1973) suggested that larval herring are active at the surface at night, the activity was associated with vertical migration and not feeding. Instead, we feel that visual contrast or light scattering may explain our results. Ritchie (1972) suggested that turbidity reduced the ability of fish to locate prey but also decreased predation pressure. The decreased feeding capabilities of larger planktivorous fishes in turbid conditions (Vinyard \& O'Brien, 1976; Gardner, 1981) are a function of the limitation of visual field, as discussed earlier. Thus, in turbid conditions, if larvae are able to maintain high feeding rates, their advantage increases. Blaber \& Blaber (1980) suggested that turbidity was the most important factor affecting juvenile fish abundance in estuaries, with highest fish abundance during highest turbidity levels; moreover, where a gradient of turbidity existed, fish abundance was highest in the most turbid waters. Natural sediment suspension concentrations may reach some $100 \mathrm{mg} \cdot \mathrm{l}^{-1}$ in estuaries (Auld \& Schubel, 1978). It would thus be interesting to use suspension concentrations between 0 and $500 \mathrm{mg} \cdot 1^{-1}$ to determine if a lower optimum level exists for larval herring. The increased feeding capabilities, however, certainly occur within environmentally realistic suspension concentrations.

\section{Summary}

Larval Pacific herring are able to feed at a greater rate under moderate suspensions of fine-grained sediment and volcanic ash than under clear-water control conditions; this ability decreases with increasing suspension level. Two mechanisms are suggested to account for the enhancement of feeding over controls. First, we suggest that in the small visual field of the larvae, contrast is enhanced by the background provided by the sediment particles. Secondly, the particles scatter light in all directions, possibly resulting in greater illumination of the food particles, which in turn can decrease the transparency of the food particles. Feeding abilities of the larval herring are thus adapted to residence in the turbid estuarine environments occupied during the larval stage.

\section{Acknowledgements}

The work upon which this publication is based was supported in part by funds provided by the Office of Water Research and Technology (Grant No. 14-34-0001-1461), U.S. Department of the Interior, Washington, D.C., through the Washington Water Research Center and the Water Resources Research Institute, Oregon State University. We thank M. Dutchuk and M. Garreton for technical assistance and G. L. Taghon and S. E. Kaupp for critical reviews of the manuscript.

\section{References}

Auld, A. H. \& J. H. Schubel, 1978. Effects of suspended sediment on fish eggs and larvae: a laboratory assessment. Estuar. Coast. mar. Sci. 6: 153-164.

Blaber, S. J. M. \& T.G. Blaber, 1980. Factors affecting the distribution of juvenile estuarine and inshore fish. J. Fish Biol. 17: 143-162.

Blaxter, J. H. S., 1968. Visual tresholds and spectral sensitivity of herring larvae. J. exp. Biol. 48: 39-53.

Blaxter, J. H. S., 1973. Monitoring the vertical movements and light responses of herring and plaice larvae. J. mar. biol. Ass. U.K. 53: 635-647.

Blaxter, J. H. S., 1974. The eyes of larval fish. In M. A. Ali(ed.), Vision in Fishes. Plenum Press, N.Y.: 427-443.

Blaxter, J. H.S. \& M. P. Jones, 1967. The development of the retina and retinomotor responses of the herring. $J$. mar. biol. Ass. U.K. 47: 677-697.

Blaxter, J. H. S. \& M. E. Staines, 1971. Food searching potential in marine fish larvae. In D. J. Crisp (ed.), 4th Europ. mar Biol. Symp. Cambridge Univ. Press, Cambridge: 467-485.

Boehlert, G. W., 1984 in press. Abrasive effects of Mt. St. Helens ash upon epidermis of yolk-sac larvae of Pacific herring. Clupea harengus pallasi. Mar. envir. Res. 12: $113-126$

Checkley, D. M., 1982. Selective feeding by Atlantic herring Clupea harengus larvae on zooplankton in natural assemblages. Mar. Ecol. Prog. Ser. 9: 245-253.

Confer, J. L.\& P. I. Blades, 1975. Omnivorous zooplankton and planktivorous fish. Limnol. Oceanogr. 20: 571-579.

Confer, J. L., G. L. Howick, M. H. Corzette, S. L. Kramer, S. Fitzgibbon \& R. Landesberg, 1978. Visual predation by planktivores. Oikos 31: 27-37. 
Doan. K. H., 1941. Relation of sauger catch to turbidity in Lake Erie. Ohio J. Sci. 41: 449-452.

Ewart, J. W. \& C. E. Epifanio, 1981. A tropical nagellate food for larval and juvenile oysters, (Crassostrea virginica) Gmelin. Aquaculture 22: 297-300.

Fruchter, J. S., D. E. Robertson, J. C. Evans, K. B. Olsen, E. A. Lepel, J. C. Laul, K. H. Abel, R. W. Sanders, P. D. Jackson. N. W. Wogman, R. W. Perkins, H. H. Van Tuyl, R. H. Beauchamp, J. W. Shade, J. L. Daniel, R. L. Erikson, G. A. Sehmel, R. N. Less, A. V. Robinson, O. R. Moss, J. K. Briant \& W. C. Cannon, 1980. Mount St. Helens Ash from the 18 May 1980 eruption: Chenical, physical, mineralogical. and biological properties. Science 209: 1116-1125.

Gardner, M. B., 1981. Effects of turbidity on feeding rates and selectivity of bluegills. Trans. Am. Fish. Soc. 110: 446-450.

Graham, J.J., 1972. Retention of larval herring within the Sheepscot Estuary of Maine. Fish. Bull., U.S. 70: 299-305.

Heinle, D. R. \& D. A. Flemer, 1975. Carbon requirements of a population of the estuarine marine copepod Euryremora affinis. Mar. Biol. 31: 235-247.

Houde, E. D., 1978. Critical food concentrations for larvae of three species of subtropical marine fishes. Bull. mar. Sci. 28 : $395-411$

Howick, G. L. \& W. J. O'Brien, 1983. Piscivorous feeding behavior of large mouth bass: An experimental analysis. Trans. Am. Fish. Soc. 112: 508-516.

Hunter, J. R., 1972. Swimming and feeding behavior of larval anchovy. Engraulis mordax. Fish. Bull., U.S. 70: 821-838.

Hunter, J. R. (ed.), 1976. Report of a colloquium on larval fish mortality studies and their relation to fishery research. Jan. 1975. NOAA Tech. Rep. NMFS Circ. 395.

Hunter, J. R., 1981. Feeding ecology and predation of marine fish larvae. In $R$. Lasker (ed.), Marine Fish Larvae. Washington Sea Grant, Seattle: 33-77.

Hunter, J. R., S. E. Kaupp \& J. H. Taylor, 1981. Effects of solar and artificial ultraviolet- $B$ radiation on larval northern anchovy, Engraulis mordax. Photochem. Photobiol. 34: 477-486.

Hunter, J. R., J. H. Taylor \& H. G. Moser, 1979. Effect of ultraviolet irradiation on eggs and larvae of the northern anchovy, Engraulis mordax, and Pacific mackerel, Scomber japonicus. during the embryonic stage. Photochem. Photobiol. 27: 1-14.

Jones, M. P., F. G. T. Holliday \& A. E. G. Dunn, 1966. The ultrastructure of the epidermis of larvae of the herring ( $\mathrm{Clu}$ pea harengus) in relation to the rearing salinity. J. mar. biol. Ass. U.K. 46: $235-239$.

Longwell, A. C. \& J. B. Hughes, 1981. Cytologic, cytogenetic, and embryonic state of Atlantic mackerel eggs from surface waters of the New York Bight in relation to pollution. Rapp. P. V. Reun. Cons. Int. Explor. mer 178: 76-78.

Moore, J. W.\& I. A. Moore, 1976. The basis of food selection in nounders, Platichthy's flesus (L.) in the Severn estuary. J. Fish. Biol. 9: 139-156.
Muncy, R.J., G.J. Atchison. R. V. Bulkley, B. W. Menzel, L. G. Perry \& R. G. Summerfelt, 1979. Effects of suspended solids and sediment on reproduction and early life of warmwater fishes: A review. U.S. Envir. Prot. Ag. Corvallis, Oregon, $101 \mathrm{pp}$

O'Connell, C. P.. 1981. Development of organ systems in the northern anchovy, Engraulis morclar and other teleosts. Am. Zool. 21: 429-446.

O'Connell. C. P. \& L. P. Raymond. 1970. The effect of food density on survival and growth of Engraulis mordax (Girard) in the laboratory. J. exp. mat. Biol. Ecol. 5: 187-197.

Pearcy. W. G. \& S. S. Myers, 1974. Larval fishes of Yaquina Bay, Oregon: A nursery ground for marine fishes? Fish. Bull., U.S. 72: 201-213.

Ritchie, J. C., 1972. Sediment, fish, and fish habitat. J. Soil Wat. Conserv. 27: 124-125.

Rosenthal, H., 1971. Wirkung von 'Rotschlamm' auf Embryonen und Larven des Heıings, Clipea harengus. Helgoländer wiss. Meeresunters. 22: 366-376.

Rosenthal, H. \& D. F. Alderdice, 1976. Sublethal effects of environmental stressors, natural and pollutional, on marine fish eggs and larvae. J. Fish. Res. Bd Can. 33: 2047-2065.

Rosenthal, H. \& G. Hempel, 1970. Experimental studies in feeding and food requirements of herring larvae (Clupea harengus L.). In J. H. Steele (ed.), Marine Food Chains. Univ. Calif. Press, Berkeley: 344-364.

Sherk, J. A., J. M. O'Connor \& D. A. Neumann, 1975. Effects of suspended and deposited sediments on estuarine environments. In L. E. Cronin (ed.), Estuarine Research. Academic Press, N.Y. 2: 541-558.

Steinfeld, J. D., 1972. Distribution of Pacific herring spawn in Yayuina Bay, Oregon, and observations on mortality through hatching. M.S. Thesis, Ore. St. Univ., Corvallis, $75 \mathrm{pp}$.

Swenson, W. A. \& M. L. Matson, 1976. Influence of turbidity on survival, growth, and distribution of larval lake herring (Coregonus artedii). Trans. Am. Fish. Soc. 105: 541-545.

Theilacker, G. H. \& M. F. McMaster, 1971. Mass culture of the rotifer Brachionus plicatilis and its evaluation as a food for larval anchovies. Mar. Biol. 10: 183-188.

Vinyard, G. L. \& W. J. O'Brien, 1976. Effects of light and turbidity on the reactive distance of bluegill (Lepomis macro(hirus). J. Fish. Res. Bd Can. 33: 2845-2849.

Weihs, D., 1980. Respiration and depth control as possible reasons for swimming of northern anchovy, Engraulis mordax, yolk-sac larvae. Fish. Bull., U.S. 78: 109-118.

Weinstein, M. P., S. L. Weiss, R. G. Hodson \& L. R. Gerry, 1980. Retention of three taxa of postlarval fishes in an intensively flushed tidal estuary, Cape Fear River, North Carolina. Fish. Bull., U.S. 78: 419-436.

Received 12 December 1983; in revised form 1 August 1984; accepted 6 September 1984. 